\title{
The Industry Cluster Approach for Tourism Development of Central Vietnam
}

\author{
Truong Hong Trinh ${ }^{1}$ \\ ${ }^{1}$ University of Economics, The University of Danang, Vietnam \\ Correspondence: Truong Hong Trinh, University of Economics, The University of Danang, Vietnam. Tel: \\ 84-511-352-5459. E-mail: trinh.th@due.edu.vn
}

Received: March 8, 2016

Accepted: April 6, 2016

Online Published: April 18, 2016

doi:10.5539/ijbm.v11n5p167

URL: http://dx.doi.org/10.5539/ijbm.v11n5p167

\begin{abstract}
Industry cluster is frequently mentioned in the literature of the regional economic development, but there are a few studies about identifying competitive clusters in the region. For this reason, the paper approaches cluster analysis for identifying competitive clusters in Central Vietnam. From location quotient and shift-share analysis, the result reveals that tourism cluster is a competitive cluster for the regional economic development. Then, the study develops the tourism cluster in central Vietnam that includes tourism cluster profile, tourism production network, and tourism value chain. Moreover, the study result provides a basic framework for industry cluster analysis that help policy makers and economic developers to understand economic activities, characteristics of competitive cluster and supranational characters in the regional economy, then deliver strategy and policies for tourism cluster development of Central Vietnam.
\end{abstract}

Keywords: industry cluster, regional economic development, tourism cluster, tourism value chain, Vietnam

\section{Introduction}

The regional economic development has become a major issue that has been increasingly discussed in both the academic and the practice literature. However, most development programs are limited in administrative geography that may not realize the importance of identifying inherent interrelationships in the regional economy (Carroll \& Stanfield, 2001). In fact, there are many different approaches for regional economic development, ranging from industry agglomeration to industry cluster (Bekele \& Jackson, 2006), in which industry cluster studies are increasingly interested by policy makers and economic developers in recent years. Porter (1996) also indicated that cluster policy supports the development of all clusters, not just to choose among them, and encourages initiative at the local level, in which the clustering effort will enhance the competitive competency in the regional economy.

In the literature, many researchers have proposed ways to identify competitive clusters for regional economic development ranging from input/output analysis to cluster analysis (Carroll \& Stanfield, 2001). An industry cluster is considered to have a comparative advantage if the output, productivity and growth of a cluster are high relative to other regions. In addition, the realities of global competition require an understanding on the complexities of interactions with multiple stakeholders in the global supply chain (Youngdahl \& Loomba, 2000). From both theoretical and practical perspectives, this paper is to provide an analysis framework for policy makers and economic developers to understand economic activities and characteristics of competitive cluster in the region. The industry cluster approach is employed to identify competitive clusters under the distinct socio-economic conditions of Central Vietnam. Both quantitative and qualitative analyses are employed to develop tourism cluster profile, tourism production network, and tourism value chain in global chain perspective.

\section{Methodology}

\subsection{Industry Cluster}

Industry cluster is defined as "a geographically proximity group of interconnected enterprises associated with institutions in a particular field, linked by commonalities and complementarities" (Porter, 2000). Industry cluster has a scope broader than an industry or an industry sector by interrelationships in economic activities and ability to create competitive advantages in the region. A cluster is not simply the result of the presence of a large enterprise, or of multiple enterprises in the same industry. Rather, industry cluster refers to the ability of the 
enterprises in an industry to interact in ways that create competitive advantages through the creation and incorporation of new knowledge into products and the processes that produce them. Porter (1990) argues that any region or country can develop competitive clusters for the regional economic development. Figure 1 shows differences between cluster-based policy and traditional industrial policy.

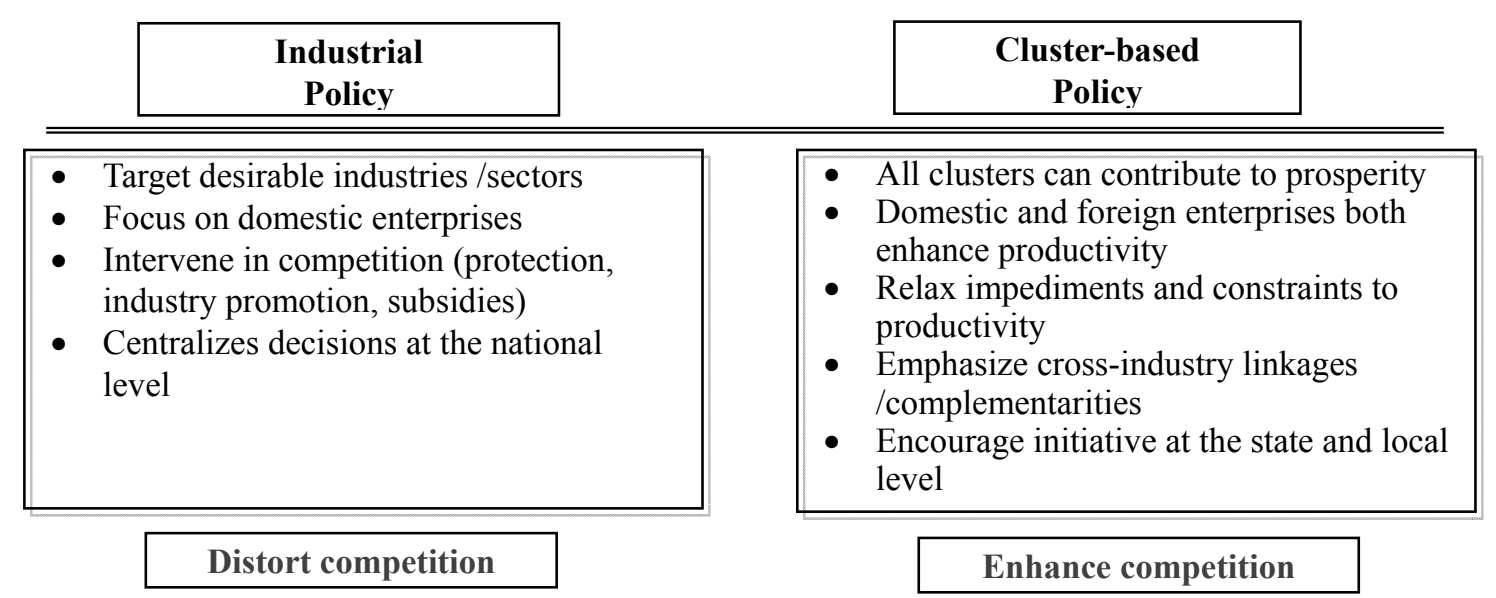

Figure 1. Porter's view of cluster policy vesus industrial policy (Woodward, 2005)

\subsection{Analysis Framework}

The industry cluster approach requires regions to undertake economic base analysis to identify competitive clusters that are driving the regional economy and delivering services with competitive advantages in responding to global markets. Cluster analysis is a tool used to identify those areas of the local economy in which comparative advantage(s) exists. These clusters must be understood and applied as regional economic systems (The National Governors Association [NGA], 2002), and cluster analysis is a powerful tool to develop cluster-based economic development strategies. 


\begin{tabular}{l}
\hline \multicolumn{1}{c|}{ Products } \\
Defining of \\
Data Sources \\
Identifying of \\
Competitive \\
Clusters
\end{tabular}

Modeling of

- Cluster profile

-Production netwo $\mathrm{k}$

- Value chain

Developing of

Strategy and

Policies

\section{Define Region}

Define geographic area for studying industry cluster. The region of Central Vietnam

\section{Identify Key Partners}

Local tourism authorities, Industry \& Trade Associations, Researchers at universities, Local economic developers

\section{Quantitative Analysis}

Use GSO data and identify clusters by using 3 criteria:

- LQ> 1.25

- Average wage $=10 \%$ above national average

- Growth rate $>$ national growth rate
Qualitative Analysis

Conduct interviews with enterprises and focus groups:

- Vertical and horizontal linkages

- Relationships of enterprises with supporting industries and economic foundations

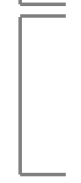

\section{Develop Strategy \& Policies}

- Development orientation and strategy

- Policies and actions of industry cluster

\section{Competitiveness Analysis}

Conduct Shift-Share analysis. Collect additional information about collaboration, competition and challenges.
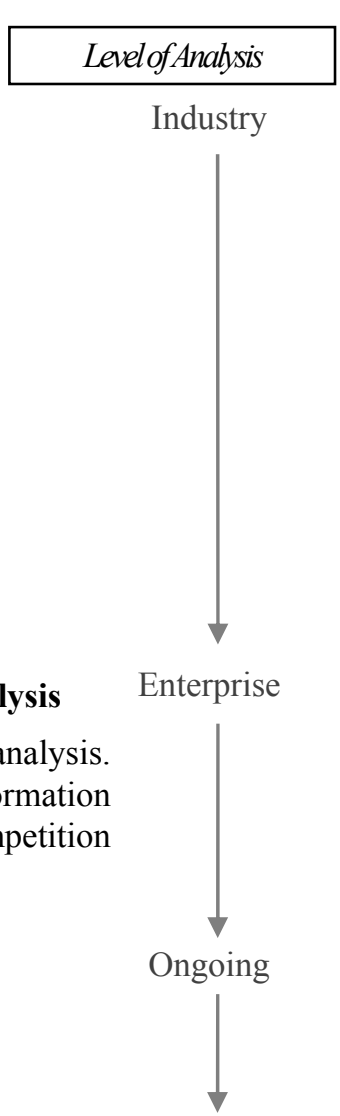

Figure 2. Methodological framework for industry cluster analysis (Woodward, 2005)

There are two primary analysis methods in identifying industry clusters (Carroll \& Stanfield, 2001). The input-output analysis determines individual interconnections through some national production function measures that provide a fairly good approximation of the local economic base. However, this approach assumes that the local linkages are the same as the national model that may not suitable for the regional economy. Industry cluster analysis eliminates with predetermination problem as in the input-output analysis. This cluster analysis is based on geographic proximity and inherent existing linkages of industry cluster in the region. The industry cluster approach requires several data analysis methods such as qualitative analysis, quantitative analysis, and competitive analysis. Figure 2 describes a framework for industry cluster analysis. This cluster analysis is a dynamic, iterative, and ongoing process that involves key partners that policy makers and economic developers about the needs and challenges of enterprises in the industry cluster (Mayer, 2005).

\subsection{Data Source}

Cluster analysis requires many data sources. Published statistical data is used in quantitative analysis to identify potential clusters and to analyze competitive clusters. Survey data is used in qualitative analysis to develop tourism cluster profile, tourism production network, and tourism value chain. Qualitative analysis describes how clustered enterprises work and connect together through buyer-supplier relationship and other form of information network. Qualitative inquiries require cooperation with such key partners as local tourism authorities, industry and trade associations, researchers at university, local economic developers. These partners function as link to gain access to industry representatives. Questionnaires are designed by cluster analysts, and then revised by focus groups before delivering to interviewees.

The survey was carried out with 102 tourism enterprises in Central Vietnam, including tour operators, travel agents, restaurants and hotels, transportation enterprises. The objective of the survey is to obtain information about linkages, cooperation and competition among tourism enterprises, relationships with supporting industries and economic foundations. In addition, the study also investigates 320 visitors on the level of expenditure and customer satisfaction. From these analyses, it will provide guidelines for policy makers to deliver strategy and policies for tourism cluster development. 


\section{Cluster Analysis}

\subsection{Define Region}

The region under the study is the middle part of Central Vietnam which includes Hue-Danang-Quang Nam. The region has a great combination of the natural and cultural attributes, including four of the nation's six UNESCO World Heritage Sites: Complex of Hue Monuments, Hoi An Ancient Town and My Son Sanctuary and PhongNha-Ke Bang National Park in Dong Hoi. Danang Beaches have been ranked among the "World's Most Luxurious Beaches" with Forbes magazine, which the beaches also have benefits from its location at the hub of the four world heritage sites.

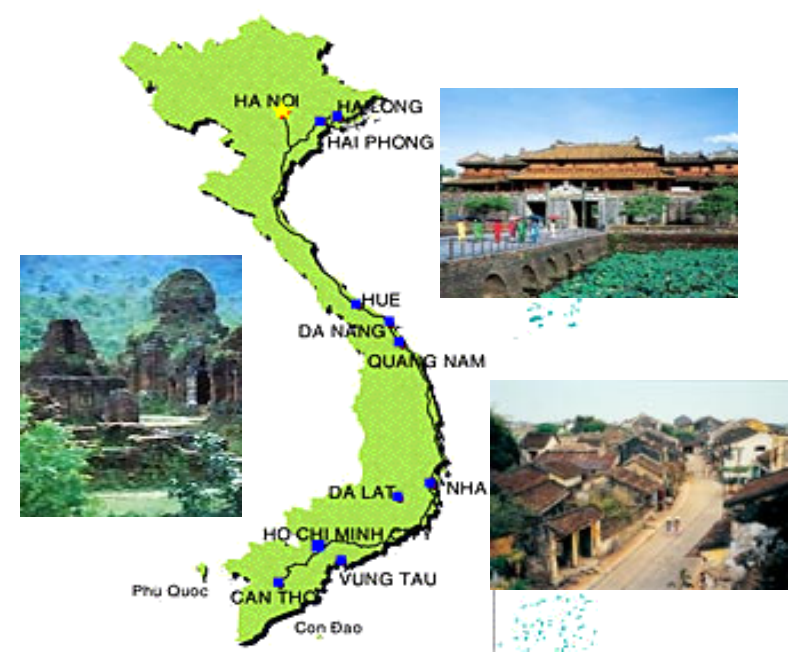

Figure 3. World heritages of Hue-Danang-Quang Nam

The local governments, enterprises and communities have realized abundant potentiality of tourism development. In fact, tourism industry makes a significant contribution to local budgets, and it has created jobs and income for the population in recent years. In addition, cultural tourism and eco-tourism have contributed to the conservation of resources, the natural environment, biodiversity and cultural values, and also helped increasing income for local communities as well as raising the level of overall development (Luong, 2005).

\subsection{Competitive Clusters}

Quantitative analysis employed statistical data to identify potential clusters through a triangulation strategy of employment concentration, wage levels, and relative growth, in which provide a comprehensive analysis of the regional economy. This quantitative analysis employs the following criteria.

- $\quad$ Location Quotient (LQ) $>1.25$

- $\quad$ Average wages $=10 \%$ above national average

- $\quad$ Growth rate $>$ national growth rate

\section{Criteria 1: Location Quotient Analysis}

$$
\mathrm{LQ}_{\mathrm{i}}=\frac{\mathrm{e}_{\mathrm{i}} / \mathrm{e}}{\mathrm{E}_{\mathrm{i}} / \mathrm{E}}
$$

Where: $\mathrm{e}_{\mathrm{i}}$ : $\quad$ local employment in industry $\mathrm{i}$;

e: total local employment;

$\mathrm{E}_{\mathrm{i}}$ : $\quad$ national employment in industry $\mathrm{i}$;

E: $\quad$ total national employment;

$\mathrm{LQ}_{\mathrm{i}}$ : location quotient in industry $\mathrm{i}$;

If the LQ larger than 1.0, it indicates that the local share of employment exceed the national share of employment in the same industry and it means that locally the industry concentrated and might have a 
comparative advantage.

\section{Criteria 2: Wage Level Analysis}

Wage levels are important determinants of the value that is placed on the production of certain goods. The objective is to find industry segments with wage levels that are significantly above the national average.

\section{Criteria 3: Growth Rate Analysis}

The growth rate analysis identifies industry segments that are growing faster in the region than in the nation as a whole. Knowing which industries are fast growing is important because economic developers need to know which industries are doing well.

$$
E m p_{t}=\operatorname{Emp}_{b}(1+r)^{n}
$$

Where: Emp : terminal year employment;

Emp $_{\mathrm{b}}$ : base year employment;

$\mathrm{n}$ : number of years in the time span;

r: $\quad$ growth rate over each interval;

Table 1. Economic statistics by sectors for Hue-Danang-Quang Nam

\begin{tabular}{lllll}
\hline Economic Sectors & Number of Enterprises & Job Growth & Wage Growth & Location Quotient \\
\hline Agriculture and forestry & 33 & $-11 \%$ & $5 \%$ & 0.21 \\
Fishery & 14 & $0 \%$ & $15 \%$ & 0.31 \\
Mining and quarrying & 69 & $17 \%$ & $37 \%$ & 0.75 \\
Manufacturing & 756 & $11 \%$ & $21 \%$ & 0.85 \\
Electricity, gas and water supply & 4 & $7 \%$ & $27 \%$ & 1.12 \\
Construction & 647 & $6 \%$ & $21 \%$ & 1.48 \\
Trade, repairing service & 2041 & $8 \%$ & $18 \%$ & 1.24 \\
Hotels and restaurants & 324 & $22 \%$ & $35 \%$ & 2.39 \\
Transport and communications & 315 & $7 \%$ & $23 \%$ & 1.10 \\
Finance and banking service & 15 & $20 \%$ & $41 \%$ & 0.29 \\
Other services & 328 & $10 \%$ & $25 \%$ & 0.72 \\
\hline
\end{tabular}

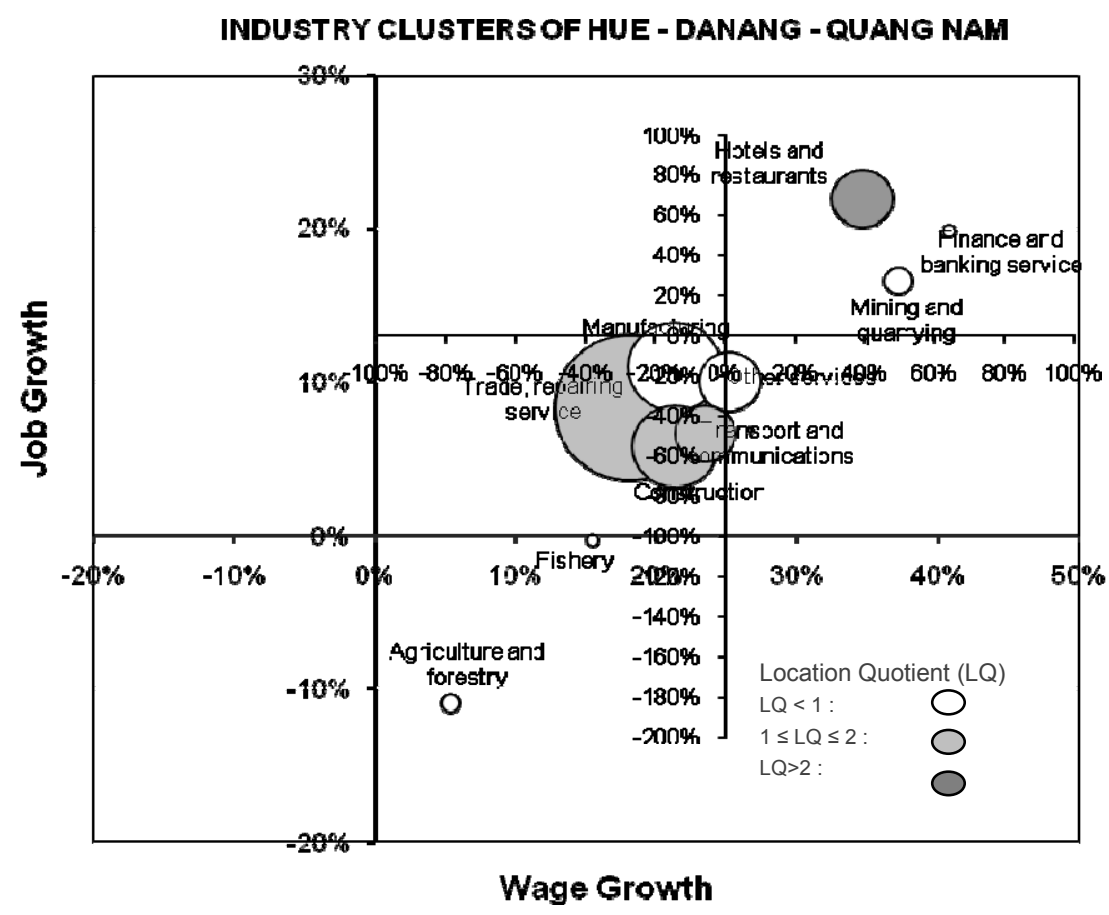

Figure 4. Bubble chart for Hue-Danang-Quang Nam 
Industry clusters of Hue - Danang - Quang Nam are presented in Figure 4 on the main diagram with two axes of wage growth and job growth. Most industries have a positive growth of job and wage, but fishery, agriculture and forestry have a negative job growth. However, most industries have a negative growth comparing with average growth of whole country as shown in the sub-axes. Some industries such as hotels and restaurants, finance and banking service, mining and quarrying have job and wage growth in the region higher than growth in the country. However, location quotient of hotels and restaurants is very high $(\mathrm{LQ}=2.39)$. This indicates that tourism industry has a significiant growth rate, and this is a sign for presence of cluster and comparative advantage in the region.

\subsection{Shift-Share Analysis}

Although location quotients are useful for identifying potential clusters of a region and giving a picture of local economy, they do not explain the sources of change over time or describe how the performance of a local economy differs from that of the nation. Shift-share analysis is a method to analyse differences between growth in a local economy and growth in the national or other regional economies. The method allows for isolating the effect of local influences on growth from effects that operate industry-wide or at the national level.

The method divides local employment into three components:

- $\quad$ National Share (NS);

- Industrial Mix (IM), and;

- Local Factor (LF).

The national share reflects national trends. The industrial mix refers to specific trends in the industry. Local factors account for local influences on an industry's performance.

McLean and Voytek (1992) provide the following formula:

$$
\begin{gathered}
\text { Local Employment }=\text { National Share }+ \text { Total Shift } \\
\text { Total Shift }=\text { Industrial Mix }+ \text { Local Factors } \\
\quad \text { National Share: } \mathrm{NS}_{\mathrm{i}}=\mathrm{e}_{\mathrm{i}}^{\mathrm{t}-1} \times\left(\mathrm{E}^{\mathrm{t}} / \mathrm{E}^{\mathrm{t}-1}\right) \\
\text { Industrial Mix: } \mathrm{IM}_{\mathrm{i}}=\mathrm{e}_{\mathrm{i}}^{\mathrm{t}-1} \times\left(\left(\mathrm{E}_{\mathrm{i}}^{\mathrm{t}} / \mathrm{E}_{\mathrm{i}}^{\mathrm{t}-1}\right)-\left(\mathrm{E}^{\mathrm{t}} / \mathrm{E}^{\mathrm{t}-1}\right)\right) \\
\text { Local Factors: } \mathrm{LF}_{\mathrm{i}}=\mathrm{e}_{\mathrm{i}}^{\mathrm{t}-1} \times\left(\left(e_{i}^{t} / e_{i}^{t-1}\right)-\left(\mathrm{E}_{\mathrm{i}}^{\mathrm{t}} / \mathrm{E}_{\mathrm{i}}^{\mathrm{t}-1}\right)\right)
\end{gathered}
$$

Where: ei and Ei: local and national employment in industry $\mathrm{i}$;

e and E: total local and total national employment ;

$\mathrm{t}-1$ and $\mathrm{t}$ : beginning and end of the time period, respectively;

Table 2. Shift-share analysis for Hue-Danang-Quang Nam 2000-2005

\begin{tabular}{lccccccc}
\hline Economic sectors & $\mathrm{E}_{\mathrm{i}}^{2000}$ & $\mathrm{E}_{\mathrm{i}}^{2005}$ & $\mathrm{e}_{\mathrm{i}}^{2000}$ & $\mathrm{e}_{\mathrm{i}}^{2005}$ & $\mathrm{NS}_{\mathrm{i}}$ & $\mathrm{IM}_{\mathrm{i}}$ & $\mathrm{LF}_{\mathrm{i}}$ \\
\hline Agriculture and forestry & 218552 & 203479 & 2709 & 1518 & 4942 & -2420 & -1004 \\
Fishery & 37253 & 31231 & 348 & 342 & 635 & -343 & 50 \\
Mining and quarrying & 147933 & 172931 & 2148 & 4624 & 3918 & -1407 & 2113 \\
Manufacturing & 1543590 & 3049276 & 54779 & 92172 & 99930 & 8283 & -16041 \\
Electricity, gas and water supply & 15987 & 23687 & 679 & 947 & 1239 & -233 & -59 \\
Construction & 493159 & 954545 & 37902 & 50277 & 69142 & 4220 & -23085 \\
Trade, repairing service & 367063 & 671845 & 19928 & 29702 & 36353 & 121 & -6773 \\
Hotels and restaurants & 60416 & 110644 & 3502 & 9447 & 6388 & 25 & 3034 \\
Transport and communications & 205282 & 303531 & 8609 & 11862 & 15705 & -2976 & -867 \\
Finance and banking service & 15643 & 46726 & 198 & 489 & 361 & 230 & -102 \\
Other services & 95669 & 270662 & 4331 & 6993 & 7901 & 4352 & -5260 \\
Total & 3200547 & 5838557 & 135133 & 208373 & 246515 & 9853 & -47995 \\
\hline
\end{tabular}

Source: General Statistics Office (GSO) from 2000 to 2005. 


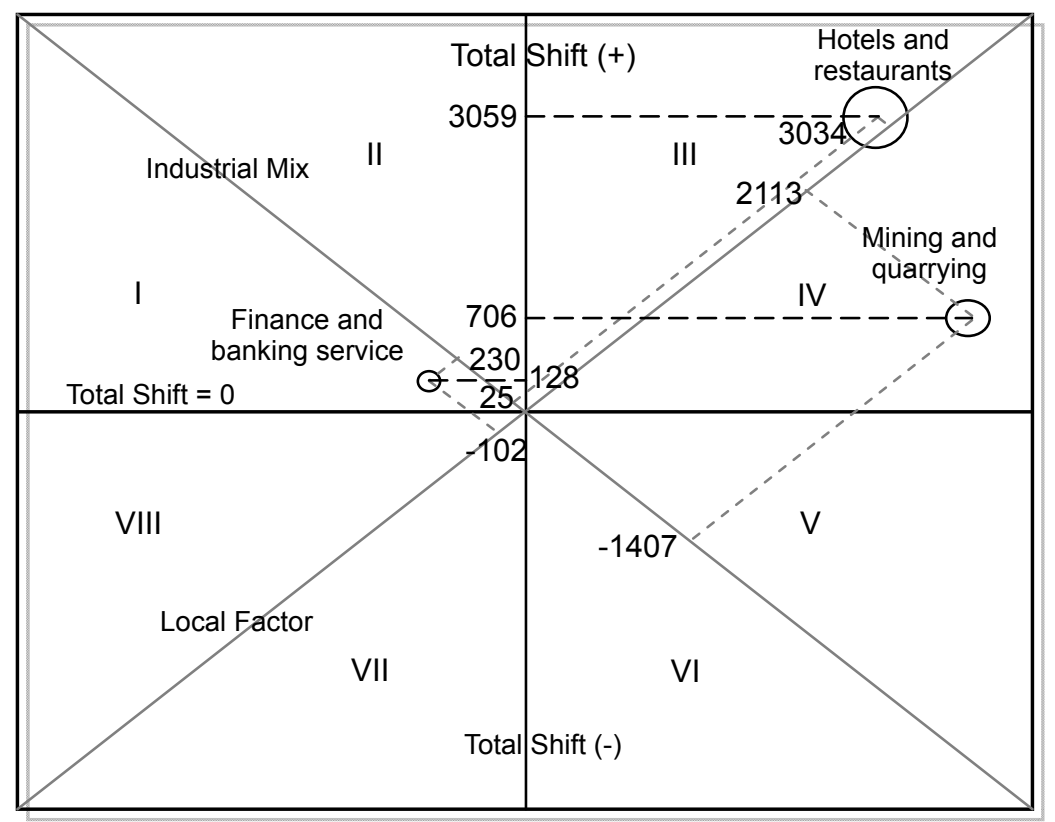

Figure 5. Graph of shift-share analysis

Shift-share analysis helps the analysts to identify industries that are strong or weak in a region compared to elsewhere. From data in Table 2, there are three sectors (hotels and restaurants; mining and quarrying; finance and banking service) that added more jobs than expected if they performed at the national average. The total shifts (sum of industrial mix and local factors) are positive, and the results are the same as in location quotient analysis. However, effects of local factors and industrial mix are different. Figure 5 shows the effects of three potential sectors. Industrial mix of tourism sector is 25 jobs meaning that the region has 25 jobs more than it would have if its structure were identical to the nation. While local factors of tourism sector is 3034 jobs. This number indicates that local businesses are more competitive than the national average. From location quotient and shift-share analysis, it reveals that tourism industry is the competitive cluster in the region.

\section{Tourism Cluster}

\subsection{Tourism Cluster Profile}

A tourism cluster is composed tourism attractions, service suppliers, supporting industries, and economic foundations that enable the system to function. Figure 6 shows the key elements of the tourism cluster in Central Vietnam. The core element in tourism cluster includes transportation, accommodation, tour operators and travel agents, and attractions. The integrations among enterprises in transportation, accommodation, and attractions are vertical linkages. Meanwhile, the horizontal linkages are established by these enterprises with distributors and facilitators. 


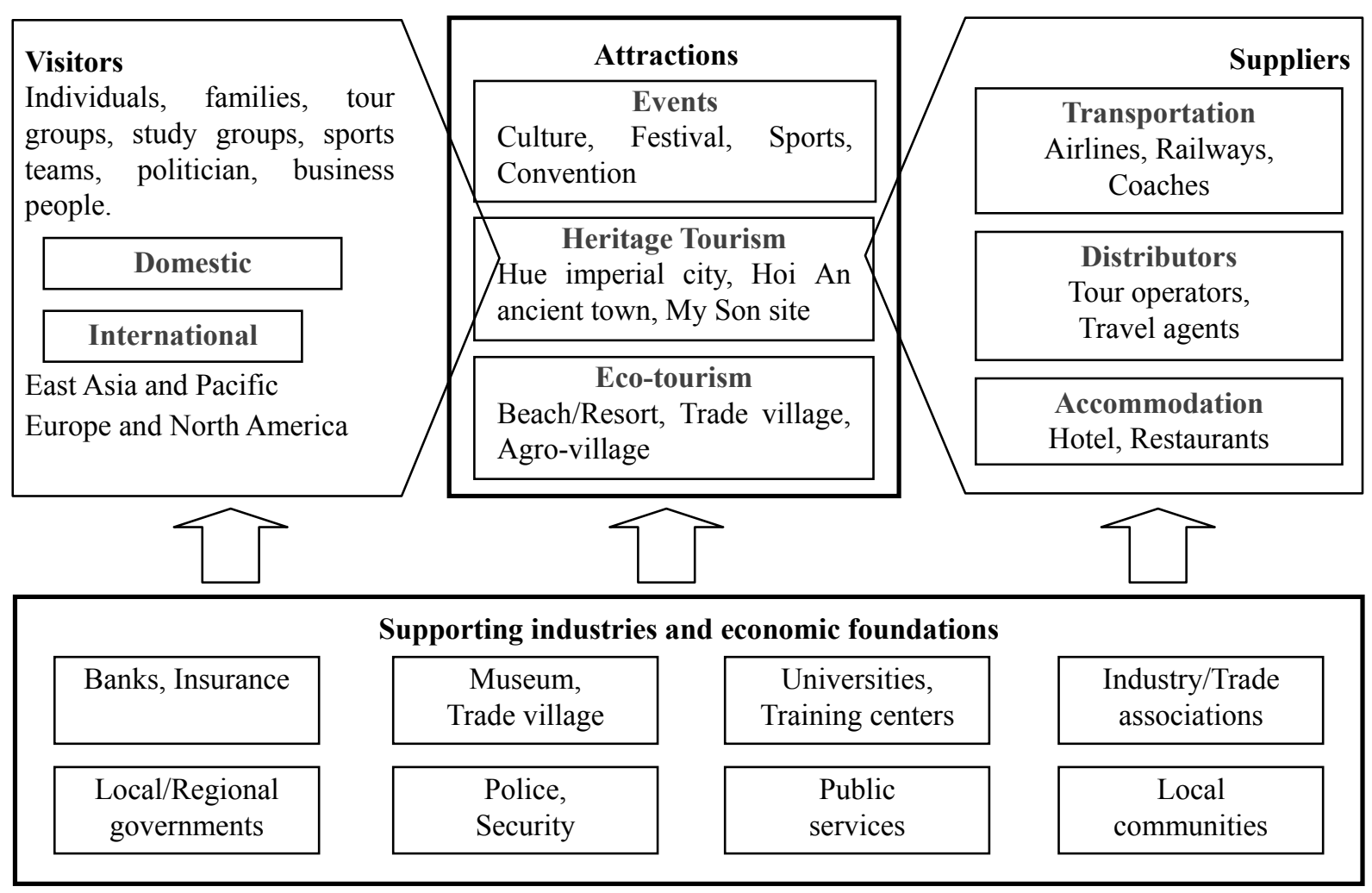

Figure 6. Tourism cluster profile

In tourism industry, the experience of the tourist will be based on the overall impression of the destination visited, which includes not only quality of hotels, restaurants but also quality of related services (Nordin, 2003). In the survey of component suppliers, direct linkages with transportation, accommodations and destinations are relatively weak. Linkages are mainly established with indirect suppliers such as equipment, raw material, and financial services.Most tourism enterprises in Central Vietnam established horizontal linkages of about $80 \%$. These linkages with distributors and facilitators are mainly to provide information and deliver tourism services. However, the interviews indicated that enterprises lack coordination in marketing efforts, and have poor information pooling. Small enterprises have difficulties in approaching customers, especially international customers. Most large enterprises have individual relationships with their tourism distributors. The survey also reveals that nearly $60 \%$ of enterprises expects to extend vertical integrations, while approximately $40 \%$ of enterprises that expected to extend horizontal integrations.

In tourism cluster, the quality of a visitor's experience depends both primary tourism attractions and complementary businesses such as hotels, restaurants, shopping outlets, and transportation facilities (Porter, 1998). In the investigation of factors impacted to tourism services, enterprises stated that human factor impacts to $70 \%$ of service quality, while visitor factor accounts for only $60 \%$, the other factors such as raw material, suppliers and travel agents also have influence on service quality. This reveals that human resource is very important factor in creating competiveness advantage via better service quality, but service quality is limited by human resource suppliers in the region.

The survey also indicated that collaboration among tourism component suppliers, distributors with supporting industries and economic foundations is relatively weak. Although supporting industries and economic foundations have influence on service quality of tourism cluster, such as government policies, safety and security Furthermore, tourism enterprises have not appraised the role of trade associations, local community, trade villages, banking services to their tourism business. 


\subsection{Tourism Production Network}

In tourism cluster, production network has many sub-clusters such as event tourism, heritage tourism, and eco-tourism with many layers as in Figure 7. Tourism enterprises can participate in one or more internal destination networks that have the potential to drive the growth and specialization of the tourism cluster (Porter, 2000).

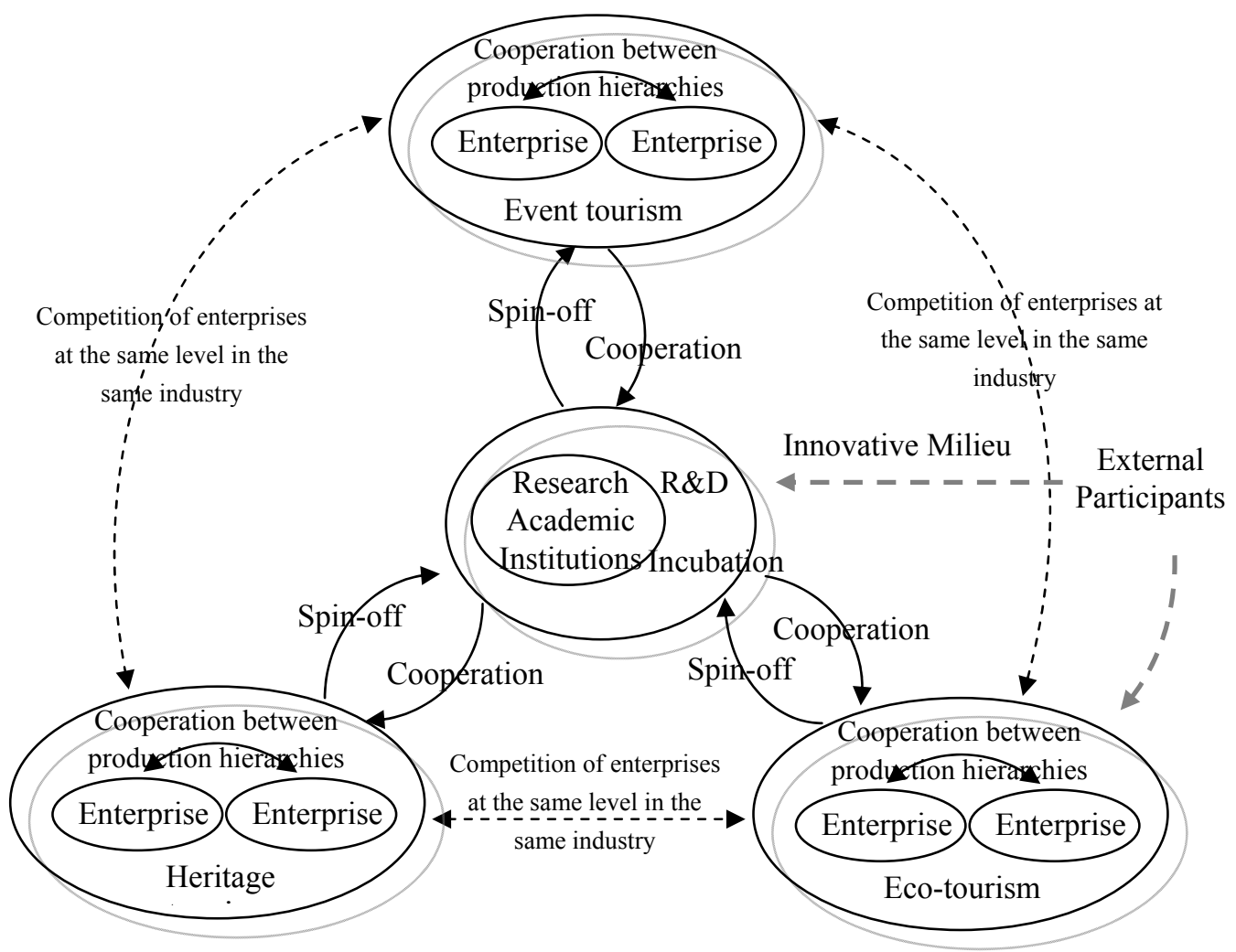

Figure 7. Tourism production network

In the investigation of collaborative activities, there are six collaborative categories in cluster study including co-inform, co-learn, co-market, co-purchase, co-produce, and co-build economic foundations (Waits, 2000). The survey result indicates that most tourism enterprises realizes the importance to promote awareness of the industry and improve communication (co-inform); sharing knowledge, innovation and training pool (co-learn). Collaborative activities in business process (co-purchase, co-produce and co-market) are currently very weak, mainly cooperation between production hierarchies in the same industry. Tourism enterprises also address collective activities (co-inform, co-learn, and co-build economic foundations) to make competitive competency in the region. The survey reveals that tourism enterprises in the same level are willing to extend collaboration in service processes. Meanwhile, tourism enterprises in the different level expect to enhance collaboration in transfer of local infrastructure, share of information, innovation and training pool.

\subsection{Tourism Value Chain}

The tourism value chain includes a wide range of activities staring from indirect providers (local input), direct providers (accommodation, transportation), attractions (heritage sites, festivals/events, and beach/resorts), and distribution systems (inbound and outbound tour) to its customers (visitors) as shown in Figure 8. The value chain is a useful tool to examine internal and external operating conditions of an enterprise or a cluster to build its competitive advantage. The study also investigates visitors from different customer segments (Low-end, Mid-end and High-end) about expenditure level on tourism services, and level of customer satisfaction. According to the survey results, reasons for visit in the region are mainly for tour $(61.27 \%)$ and historical sites (22.54\%). Other reasons (recreation, education visit, or shopping) account for a small proportion. The popular methods of transport are motorcycles (34.1\%), taxi (19.7\%), and train (7.5\%). Most low-end tourists select motorcycle and train for their travel, while high-end tourists select bus/coach and airplane for their travel. 
Although average length of trip is more than 10 days, but length of stay of less than 5 days accounts for $71.1 \%$, and level of expenditure under $100 \mathrm{USD} /$ day accounts for $73.41 \%$. These numbers reveal that value-added service is very limited and expenditure level is very low compared to 300-400 USD/day of countries such as Thailand, Singapore, and Indonesia. Moreover, the region has not established an effective cooperation among local tourism agencies and attraction sites in key tourism programs.

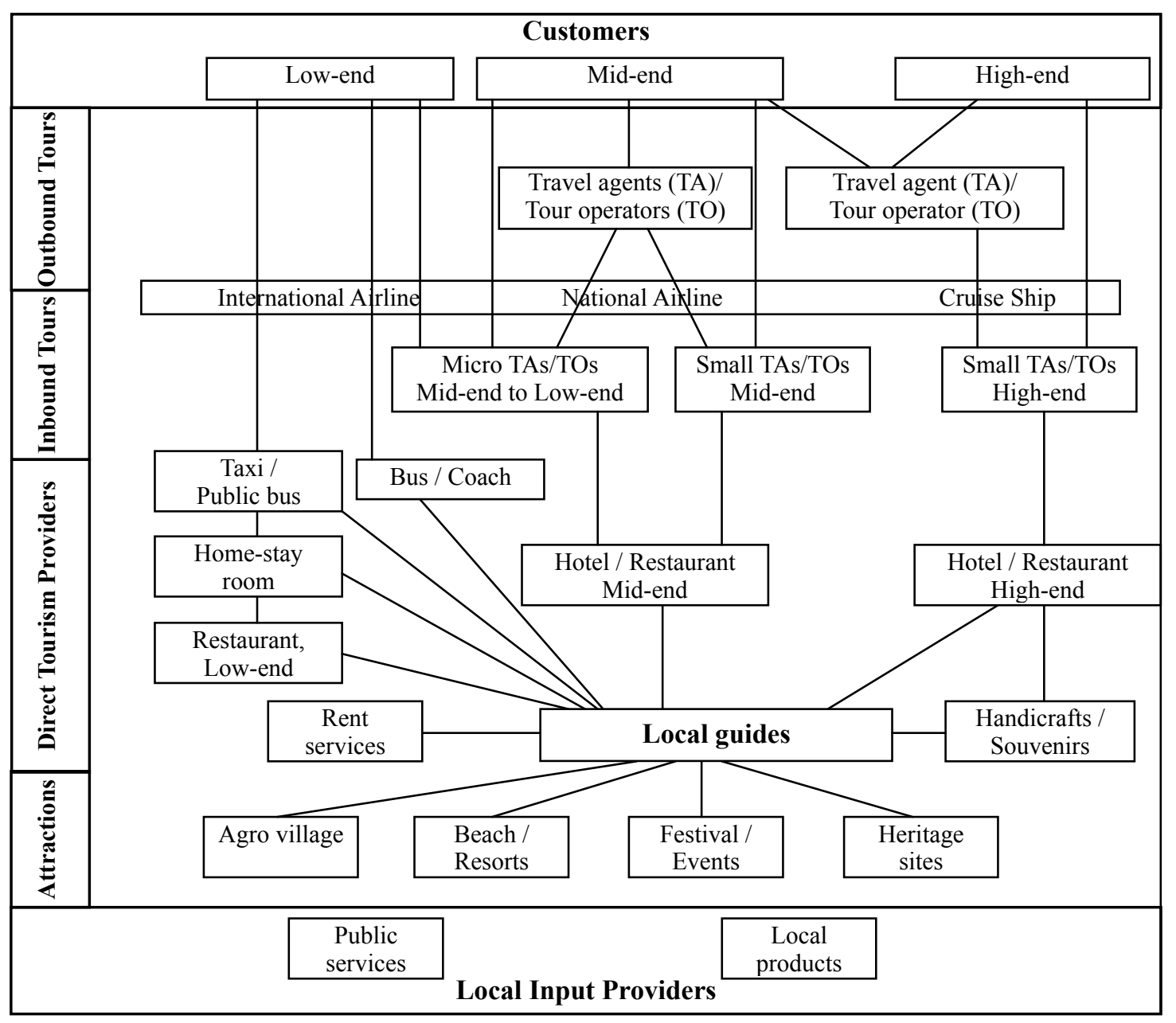

Figure 8. Tourism value chain

\section{Strategy and Polices}

Globalization has strongly influenced on tourism enterprises. Especially, enterprises operate in destinations with a very low level of integration, and mostly not work with the global partners in world tourism. In fact, most tourism enterprises have very weak relationships in cross-border cooperation as well as tourism cluster/network. Consequence of enterprise is dramatic losses in market share and opportunities for spreading featured tourism product in the region. For sustainable tourism development, the Prime Minister has been approved the development strategy for Vietnam tourism to 2020, vision 2030.The overall target to 2020 is to develop tourism to be a key economic industry with high professionalism, modern and fairly synchronously-developed tourist infrastructure; high quality, competitive and diversified tourist products imprinted with unique traditional cultural characteristics. Based on cluster analysis, globalization trends, tourism development strategy, some policies are suggested to develop tourism cluster of Central Vietnam as follows:

- Develop cooperation among countries in the region (coordinated approach at strategic level). Facilitate the development of tourism clusters/networks (consortia/alliances) across borders (share information/ best practices).

- Develop competitive products with heritage tourism and eco-tourism, enhance vertical and horizontal linkages among enterprises to create high value-added services through value chains, promote national and 
regional tourism marketing through offshore/onshore distribution systems.

- Develop human resources with priority to those related to eco-tourism, culture and event tourism, connect technological and scientific research with innovative requirements of enterprises, strengthen cooperation with local governments and local community to use tourism resources and protect natural environment.

- Develop suitable institutions and regulations to ensure active participation of local community in tourism businesses, especially entrepreneurial environment, sharing knowledge and innovation to encourage all sources for tourism development and stretch benefits to the entire community.

\section{Conclusion}

Competitive cluster development is crucial to build economic linkage, cooperation mechanism and competitive strategy in regional economy. Central Vietnam has competitive advantages and great potential in tourism development. Thus, the tourism development becomes a key industry of the region and the country, it requires taking part in tourism enterprises and local governments in developing tourism cluster in the region. The study approaches industry cluster analysis to identify and develop the tourism cluster including tourism cluster profile, tourism production network, and tourism value chain. The study result provides a basic background for policy makers and economic developers to understand economic activities, and characteristics of local tourism cluster from global chain perspective. Industry cluster concept is often easy to understand but it is hard to implement in practice because it requires an effective cooperation among related industries and local governments in the region. Although the study have addressed local tourism cluster in global chain perspective, demand forecast and demand network have not been included in the study. These limitations are also noted to researchers and practitioners for further study.

\section{Acknowledgements}

The research and development summarized in this paper is a research project with the title of "A model for local economic development of central coastal region based on industry cluster approach", code number of B2005-14-34. The research is supported by The University of Danang and the Ministry of Education and Training, Vietnam. The financial support of the research by the aforementioned sources is gratefully acknowledged.

\section{References}

Bekele, G. W., \& Jackson, R. W. (2006). Theoretical Perspectives on Industry Clusters. Research Paper 2006-5, Regional Research Institute, West Virginia University.

Carroll, M. C., \& Stanfield, J. R. (2001). Sustainable Regional Economic Development. Journal of Economic Issues, 35(2), 469-476. http://dx.doi.org/10.1080/00213624.2001.11506381

Luong, P. T. (2005). Vietnam Tourism: Current Status and Development Orientation. The workshop on "Mekong Tourism: Learning Across Borders", Chiang Mai, Thailand.

Mayer, H. (2005). Cluster Monitor. Economic Development Journal, 4(4), 40-53.

McLean, M., \& Voytek, K. (1992). Understanding Your Economy: Using Analysis to Guide Local Strategic Planning. Chicago, Illinois: Planners Press, American Planning Association.

NGA-The National Governors Association. (2002). A Governor's Guide to Cluster-Based Economic Development.

Nordin, S. (2003). Tourism Clustering \& Innovation - Paths to Economic Growth \& Development. Technical Report U 2003: 14, ETOUR, Mid-Sweden University.

Porter, M. E. (1990). The Competative Advange of Nations. New York: Free Press. http://dx.doi.org/10.1007/978-1-349-11336-1

Porter, M. E. (1996). Competitive Advantage, Agglomeration Economies, and Regional Policy. International Regional Science Review, 19(1-2), 85-90.

Porter, M. E. (1998). On Competition. Boston: The Harvard Business Review Book Series.

Porter, M. E. (2000). Location, Competition, and Economic Development: Local Clusters in a Global Economy. Economic Development Quarterly, 14(1), 15-34. http://dx.doi.org/10.1177/089124240001400105

Waits, M. J. (2000). The added value of the industry cluster approach to economic analysis, strategy development, and service delivery. Economic Development Quarterly, 14(1), 35-50. http://dx.doi.org/10.1177/089124240001400106 
Woodward, D. (2005). Porter's Cluster Strategy versus Industrial Targeting. ICIT Workshop, Orlando, Florida.

Youngdahl, W. E., \& Loomba, A. P. (2000). Service-driven global supply chains. International Journal of Service Industry Management, 11(4), 329-347. http://dx.doi.org/10.1108/09564230010355368

\section{Copyrights}

Copyright for this article is retained by the author(s), with first publication rights granted to the journal.

This is an open-access article distributed under the terms and conditions of the Creative Commons Attribution license (http://creativecommons.org/licenses/by/3.0/). 